\title{
Financial Stability of Islamic Banks: Evidence from selected Asian Countries
}

\author{
Muhammad Ali ${ }^{1 *}$, Muhammad Hanif Akhtar ${ }^{2}$, Zahid Abbas ${ }^{2}$ \\ ${ }^{1}$ Riphah School of Leadership, Islamabad, Pakistan \\ ${ }^{2}$ Bahauddin Zakraiya University, Multan, Pakistan
}

\begin{abstract}
This paper is concerned with exploring financial strength of Islamic banks in Pakistan, Bangladesh, United Arab Emirates and Saudi Arabia on the bases of bank size. Using panel regression technique the paper also made a comparison between financial strength of Middle Eastern, as well as South Asian Islamic Banks and figured that on the bases of cost to income, loan to assets and some control variables, Middle Eastern Banks are financially stronger as compared to their South Asian counterparts. The study is pioneer in analyzing the issue on inter country level.
\end{abstract}

\section{Introduction}

Intense competition, consolidation of banks, globalization, liberalization, and continuous innovations with an aim to provide Islamic friendly suitable financial services, have boosted the interest of all the concerned individuals and groups in critical evaluation of Islamic banks. Whether they are investors, depositors, regulators, bank managers, performance evaluation of the banks stand as vital for all related parties. In a greatly competitive financial market, bank performance provides signal to depositor and investors, whether to invest or withdraw funds from the bank. Depositors may also be interested in evaluating performance of banks as they are not entitled to fixed returns and nominal values of their deposits are not guaranteed. Managers are keen to know the outcomes of previous management decisions as well as to evaluate whether to improve loan service, deposit service or both in order to enhance its finance. Being responsible for safety and the soundness of the banking system and preserving public confidence, bank regulators monitor banks' performance to identify banks experiencing severe problems. Persistent monitoring of performance and financial stability is important as existing problems may remain unnoticed and can lead to financial failure in the future otherwise (Hassan and Bashir, 2003; Samad and Hassan, 1999).

Existing literature on Islamic banking unleashes various studies conducted on performance measurement of Islamic banks (Bashir, 2001; Hassan and Bashir, 2003; Samad and Hassan, 1999; Sufian, 2007). However, although studies on assessing financial performance of Islamic and conventional banks in different countries

${ }^{*}$ Corresponding author.

Email: ali62193@gmail.com have been captured by existing literature on Islamic banking and finance, but we could not detect any studies published on comparative analysis of financial performance of Islamic and conventional banks of Pakistan.

\subsection{Background of Islamic Banking and Fi- nance}

The current revival of Islamic banks started in the last thirty years. The model of Islamic banking has not been completely established. Just a small number of credit instruments have been introduced, yet. New financial instruments have been following the obligations of Islamic Shari'ah in a legal way, but they do not have much concern with the attainment of the goals of Islam (Maqasid-e-Shari'ah). There are many Islamic banks operating across the globe these days and people consider them as a feasible system in which they can invest their money with greater options. Islamic banks were primarily started to serve only the Muslims, but they are now being known to the rest of the world as well. It is now considered as one of the fastest developing fields. Islamic banks started to grow with a rapid speed a few years after the establishment of first Islamic bank in Egypt in 1963 (Ahmad et al., 2010). The contribution of Islamic banking in the banking industry of the countries has become significant and is continuously growing.

Three decades ago, there was only one Islamic bank; whereas today, there are more than three hundred Shariah-based financial institutions in more than three hundred countries (El Qorchi, 2005). Some countries are very popular now in sense of Islamic Banking e.g. 
Iran and Sudan where Islamic Banking is prevalent. Europe also couldn't deny the importance of Shariah banking and for the same reason; Islamic Banking is a niche for some European and U.S banks (Hesse et al., 2008).

Presently, \$2 trillion of global banking assets are owned by the Shariah compliant Islamic financial Institutions. Out of which, $80 \%$ is covered by pure Islamic banks and Islamic windows of non-Shariah commercial banks. Sukuk - the Islamic bond, accounts for $15 \%$, while Islamic mutual funds are composed of $4 \%$ and finally Takaful which is the name of Islamic insurance service, accounts for only $1 \%$ of global banking assests (The Economist, 2014). Talking about the Islamic banking and its composition in proportion with respect to countries, we find that the biggest player of this industry is Iran, as it accounts for $40 \%$ of global Islamic finance assets followed by Saudi Arabia, which accounts for $14 \%$. These are followed by some other countries which have less than $15 \%$ share of Islamic Finance assets, top of which is Malaysia with $10 \%$ assets while Kuwait and UAE collectively account for $9 \%$. In terms of country proportion of assets, Saudi Arabia owns 35\% of total banking assets, while the percentage is a bit lower in case of UAE, Qatar and Malaysia, which stands at 22\%, $20 \%$ and $20 \%$, respectively. Looking at the big picture, Islamic banks and financial Institutions just account for $1 \%$ of the global financial assets (Credit Suisse's, 2013). Islamic banks have a number of characteristics that make them less exposed towards risk as compared to conventional banks. For instance, if the bank has a loss in Musharaka, it will show a negative amount on the assets side, providing the depositors with more protective layer. There are certain factors that force Islamic banks to become conservative, some of them include provision of competitive and stable profits to the depositors. Similarly, Islamic banks are now having a large portion of reserves and capital through their account holders. Thus, an inquiry into the issue of financial stability is very crucial in order to see how Islamic banking industry buffers the effects of risks.

Thus, the question arises if there is a way to figure out the stability of Islamic banks? This question is empirical in nature and can be answered through the use of econometric models. Since the answer to this question may vary from bank to bank and country-wise, thus, inclusion of some data at bank-level and across country-level is essential to answer this question. The section below discusses country-wise background of Islamic banking and finance.

\subsection{United Arab Emirates}

Islamic finance industry was first commenced with the advent of Dubai Islamic Bank in UAE in the year 1975, which is the first full-fledged Shariah bank in the UAE. Since then, the Islamic banking industry started to flourish there. Soon after that, Sharjah Islamic Bank commenced its operations in 1979. At present, there are eight Shariah banks conducting their operations in UAE with a total of more than 260 branches in various areas of UAE. Looking at the factual details, we come to know that these eight banks account for $16.2 \%$ of total banking assets in the UAE, which is a significant and non-negligible part (Chamber of commerce, 2011). According to a report of Dubai Chamber of Commerce in 2011, banks in UAE are going on with a steady growth and it will continue to grow in the same manner in the next few years because of increase in population and income. Currently Global share of Islamic Banking in the UAE banking system is $9 \%$, which is in line with Kuwait. However, within UAE 22\% of total deposits are captured by these banks (Abedifar et al., 2015).

\subsection{Saudi Arabia}

Up to 2005, there were only two banks in Saudi Arabia, but presently, there are five Islamic banks operating there. Very interestingly, 64 percent of total banking assets in Saudi Arabia are owned by Shariah banks News (2006). A number of conventional banks are moving towards Shariah compliance and for the same reason Islamic banking industry is growing there with a swift speed. The national commercial bank of Saudi is also intended to become an Islamic bank in the near future. $\mathrm{SAAB}$ is an Islamic Insurance company which has recently started its operations in Saudi Arabia. It is expected that Takaful Industry will grow rapidly in the coming years and will soon account for $15 \%$ of total banking assets in the country. Currently growth rate of Islamic Banking system in the region is 13\% (Alanazi and Lone, 2016). Total deposits in the region in Islamic banks are $14.29 \%$ as compared to that of $7.25 \%$ in 2000 . These funds crossed 2000 Billion Dollar point in 2015 (Barakat et al., 2016).

\subsection{Pakistan}

In Pakistan, there was an Islamic banking movement around 1980s. However, Islamic banking actually got a virtual start in Pakistan in 2002, when dual banking system was introduced. Names of Islamic Banks in the country are Meezan Bank, BankIslami Pakistan, Albaraka, Burj bank, and Dubai Islamic. According to a study conducted in 2006, the financial assets of Islamic banks accounted for only $2.2 \%$ of the whole banks of the country (Al-Refai, 2006). Due to the issuance of a circular from SBP, all conventional banks are now needed to open Islamic windows. The securities and exchange commission of Pakistan is continuously making efforts in this regard. A number of Insurance companies like Dawood, Takaful etc. are also operating in the country (SBP, 2014). At present there are 5 full-fledged Islamic and 15 conventional banks in 
Pakistan, with 1,314 branches in 2014; however, there were only 15 branches in 2007. Talking about assets of Islamic banking in Pakistan, the figure was Rs.118 Billion in 2007 and it gradually reached to Rs.1016 Billion in 2014. Total Islamic banking assets jumped to Rs. 872 Billion in 2014 from Rs. 83 Billion in 2007 (SBP Islamic Banking Bulletin, 2014). Islamic Banks account for $9.7 \%$ of total bank deposits in the country while, $11.4 \%$ of total banking deposits are captured by Islamic banks as compared to that of $0.5 \%$ in 2003 (Ali, 2015).

\subsection{Bangladesh}

In Bangladesh, Islamic banking concerns started in 1980s. And soon after, first Islamic bank with the name of Islamic Bank Bangladesh was established in the country, in 1983. The industry is on the way to flourish in Bangladesh. In 2005, the 10\% of total cash deposited in the banks of the country was deposited in Islamic banks, out of which $10 \%$ investment denominated 5\% (Rana, 2006). In early 2005, the government of the country made a committee for amending the insurance act of the country with a view to introduce Islamic friendly Insurance services as well. By the end of 2012, total credits and deposits captured by Islamic banks in the country were $21.6 \%$ and $18.8 \%$, respectively. The total number of Islamic bank branches increased from 3 in 1983 to 751 in 2011. At present, the number of Islamic and commercial banks in Bangladesh is 8 and 48 respectively. A number of commercial banks have also opened Islamic windows.

\subsection{Objectives and Significance}

The core objective of the study is to fill an important gap in the literature of Islamic banking on financial stability. To the best of author's knowledge, there exists no study in the history of Islamic banking which empirically analyses financial stability of banks on a cross country level. Understanding the issue on a cross country basis is very important because if data are taken from only a single country, it may be affected by some control variables, which are prevailing and affecting financial dependability in that country only. Thus, data have been collected from four of the Asian countries for the purpose of comparing financial soundness of Islamic banks in an Asian context. The study has six core objectives,

1. Comparing financial stability of Islamic Banks in Middle East and South Asia.

2. Finding the determinants of financial stability of Islamic banks in Bangladesh.

3. Finding the determinants of financial stability of Islamic banks in Saudi Arabia.
4. Finding the determinants of financial stability of Islamic banks in UAE.

5. Finding the determinants of financial stability of Islamic banks in Pakistan.

6. Comparing financial stability of Islamic banks across bank size.

The study provides foundation for the exploration of stability on a cross country level.

\section{Literature Review}

\subsection{Financial Stability of Islamic banks}

Before examining the financial stability of Islamic Shariah banks, we need to look at the milestone studies that have been conducted in this field. Emerging yet integral role of Islamic finance industry has forced the researchers, scholars and stake holders to examine its efficiency as compared to the commercial banking Industry. A major portion of previous studies had focused on the comparisons of products and mechanisms that are used in Islamic and Commercial banking (Ainley et al., 2007; Jobst, 2007; Sole, 2007; Sundararajan and Errico, 2002).

Cihák and Hesse (2008), based on the data collected from 20 countries, including 397 conventional and 77 Islamic banks during the period 1993 through 2004, tested the relative financial soundness of Shariah or Islamic Banks. They categorized the results of their study on the bases of banks size and concluded that Small commercial banks were financially less strong than small Islamic banks. This may suggest that Islamic banks may face challenges related to credit risk management as they grow larger.

The efficiency and stability of commercial and Islamic banks is still considered a viable question for stake holders and researchers. Ahmad et al. (2010) conducted a study using data from 2001 through 2006, of four Asian countries, namely Pakistan, Bangladesh, Malaysia and Indonesia for investigating financial efficiency of their respective banking systems. Their efficiency estimates were based on non-parametric DEA (Data Envelopment Analysis). Findings of the study imply that Asian Islamic banks are operating at optimal level, but at the same time on the other hand they are facing managerial inefficiency in controlling their costs and are not able to utilize their resources fully. Similarly, another study concluded that large Islamic banks were financially less strong than large Commercial banks (Shajari and Mohebikhah, 2012). Talking about the latest studies in the literature, Husein (2014) examined the financial stability of Islamic banks by taking 102 banks data from Indonesia. He used Z-Score as a proxy of stability. The findings of the study determined that the size of banks has a significant im- 
pact on its stability status and over all stability of an Islamic bank in general is associated with its assets and income diversity. The study findings also suggest that large Islamic banks are financially stronger than the small banks and finally the small Islamic banks are financially stronger than those of medium sized Islamic banks. The final finding is representative of critical issues of financing risk Management for medium size Sharia'h banks.

\subsection{Z-Score as Measure of Financial Stabil- ity}

In the previous empirical literature of banking, Z-score has been a popular proxy of probability of failure of bank. Boyd et al. (1993); Boyd and Runkle (1993); Hannan and Hanweck (1988), in their studies have utilized Z-score as a measure of probability of risk, which in other words represents the likelihood of insolvency of the bank. Z-score is such a measure of bankruptcy, which measures the financial stability of bank that shows the distance from volatility, leverage and insolvency.

Cihák and Hesse (2008); De Nicolo (2001); Worrell et al. (2007), tested financial strengths of banks with Z-score. Uhde and Heimeshoff (2009) used penal data from 2600 financial institutions in the European Union using ZScore as a key variable, in order to judge the stability of German banks with various ownership structures. Kick and von Westernhagen (2009) collected penal data during the time span of 1995 through 2007. Reading along the lines of literature finally Maji et al. (2011) have also examined riskiness and likelihood of insolvency of Indian banks, using Z-score as a risk index in order to evaluate the riskiness of Indian banks and probability of book value insolvency. As per the trend of literature, the present study has also considered ZScore for measuring financial stability.

\section{Methodology}

The current study uses the data of five Islamic banks as a sample for the analysis in four of the Asian countries. The data were collected from the population of Islamic banks of two of the south Asian countries, Pakistan and Bangladesh and two of the Middle Eastern Asian countries, U.A.E. and Saudi Arabia. The study considers banks data on individual basis, collected from annual financial reports of the banks, while some data were taken from official stock exchanges of the respective countries and finally some were collected from World Bank database. Choice of these countries for the research was dictated by the fact that there exists a sizeable share of Islamic banking in these economies. Secondly, the empirical analysis has been conducted on the basis of un-consolidated financial data. In terms of an ideal situation, the study should have chosen all consolidated data. We, therefore, used consolidated data wherever available, but when consolidated data were not available for a bank, the unconsolidated data were used instead. Thirdly, the new fashion in the international industry is to open an Islamic window and most of the banks in Muslim countries are following this practice, yet the study considers data only from those banks which are fully Shariah-based.

\section{Results and Discussion}

Moving towards the regression first of all we run Hausman test for all the four countries independently. Hausman test of all the countries given a probability value of more than 0.5 , which gave us reason to run the regression using random effect model. The results of inter country random effect model are given in Table 2 and 3.

As the data are from four countries we can understand the level of diversification in the economic and regulatory conditions by the descriptive statistics. The tables above indicate that $Z$ score has a very high range its value ranging from -3 to 247 . The Maximum value of GDP growth rate is 8.6 and lowest is 4.28. Zscore is also the variable which has highest standard deviation. In order to deal with the outliers available in the concerned data, we have used robust approach. The purpose of using robust approach is that this approach gives better results by reducing the impact of those variables, which have extra-ordinarily high values of residuals. This is done in accordance with the approach introduced by Hamilton (2002).

\subsection{Regression Analysis}

In order to deal with the issue of Multicollinearity VIF test was used and then regression analysis was done, which is given in Table 4, 5 and 6 .

As per the table (4) above, for Saudi Arabia VIF is done twice because initially GDP and inflation had strong co-linearity so Inflation has been eliminated for Saudi Arabia.

Talking about Pakistan Inflation has positive relationship with the ZScore of Pakistani Islamic banks. Now let's talk about the impact of bank level independent variables on our primary dependent variable, ZScore. Banks that have a high loan to asset ratio tend to have lower values of Zscore, which means that banks with higher loan to asset ratio are generally less financially stable. Moving on towards the cost to income ratio we come to know that cost to income ratio has positive relation with financial stability of Pakistani banks. The higher this ratio the higher the ZScore and the financial stability of the banks.

According to the assumptions a negative relation be- 
Table 1: Pearson Correlation Matrix

\begin{tabular}{lccccc}
\hline & Loan to asset & Cost to income & Inflation & GDP growth & Z-Score \\
\hline Loan to asset & 1 & & & & \\
Cost to income & -0.144 & 1 & & & \\
Inflation & 0.014 & 0.148 & 1 & 1 & \\
GDP growth & 0.067 & -0.164 & $.454^{* *}$ & 0.041 & 1 \\
Z-Score & $-.440^{* *}$ & -0.132 & -0.121 & & \\
\hline$*$ * Correlation is significant at the 0.01 level & & & &
\end{tabular}

Table 2: Descriptive Statistics

\begin{tabular}{lccccc}
\hline & Range & Minimum & Maximum & Mean & Std. Deviation \\
\hline Loan to asset & 0.91 & 0.06 & 0.97 & 0.56 & 0.22 \\
Cost to income & 10.01 & -0.01 & 9.99 & 0.96 & 1.39 \\
Inflation & 39.6 & -18.9 & 20.7 & 7.82 & 9.47 \\
GDP growth & 13.8 & -5.2 & 8.6 & 4.28 & 2.83 \\
Z-Score & 249.78 & -2.92 & 246.86 & 26.16 & 34.59 \\
\hline In Unconsolidated data the figures are calculated on the basis of data from only one country
\end{tabular}

tween loans to asset is due to the reasons that if the amount of loans is more as a percentage of total assets in Pakistani Banks, then the banks are not able to properly handle those loans and thus cannot retain a steadiness in their returns. The cost to income ratio has a positive relationship with zscore, because the more the cost the banks incur as percentage of operating income the stable it is. In other words when cost to income ratio increases it also enhances the financial stability of the banks. The reason behind this relation is that effective operations and proper loan collection happens when banks increase their operating costs. Gross domestic products growth rate which is a macroeconomic level control variable also has a positive relation with financial stability of Pakistani Islamic Banks.

The results of Bangladesh are almost in opposition of Pakistan, except for results of inflation, which are in accordance with Pakistan. Inflation has a positive influence on ZScore in Bangladesh. The higher the loan to asset ratio, the more financially stable the Islamic banks are. Enlightening about cost to income ratio, we come to know that it has a strongly negative relationship with the financial stability of Islamic banks in Bangladesh. The only variable left behind for discussion in Bangladeshi contest is GDP growth which has a negative relation with Zscore. Here we have two macroeconomic variables one has positive and the other has negative relationship with our dependent variable.

Our model fits best in UAE, because in this case all our variables have significant positive relationship with the ZScore except the inflation, which has slightly negative relation with of financial stability. The strength of cost to income relation is far higher as compared to the relation of cost to income with the financial stability of Islamic Banks in UAE. GDP also has a positive relation, which means that Higher the GDP Growth rate higher is the financial stability of Islamic Banks in UAE.

The last country of our interest for this particular study is Saudi Arabia. As it was in case of UAE, of the Macroeconomic variables, GDP has positive relationship with financial stability of Islamic banks in Saudi Arabia as well. Talking about banks specific independent variables, we see that Loan to asset has strongly negative relationship with financial stability; on the other hand cost to income has positive relation with the ZScore.

As per the analysis, findings suggest that all of the four independent variables, two have positive and the remaining two have negative relationship with the only dependent variable ZScore; higher the inflation, higher the stability of banks. Loan to asset has direct relation with financial stability, which means that when loans as a percentage of total assets increase it has a good im- 
Table 3: VIF Test

\begin{tabular}{lccccc}
\hline & Pakistan & Bangladesh & UAE & Saudi Arabia & Saudi Arabia \\
\hline Loan to asset & 1.05 & 1.22 & 1.31 & 1.44 & 1.33 \\
Cost to income & 1.09 & 1.04 & 1.39 & 1.46 & 1.31 \\
GDP growth & 1.25 & 5.64 & 2.4 & 40.37 & 1.02 \\
Inflation & 1.19 & 5.25 & 2.44 & 40.77 & \\
\hline
\end{tabular}

pact on the financial stability of the bank. This is because when a bank has good portfolio of loans, it also has a high profitability. An initial observation of the zscores tells high variability within the chosen sample, with the z-score fluctuating from - 2 to 110 and 246. The high variability shows the existence of outliers within the sample data, which have a noticeable effect on the above mentioned results.

\subsection{Reasons for Country Wise Differences in Results}

Out of the two control variables inflation has negative relation with financial stability indicating that in Middle East as well as in South Asia, generally increase in price level dampens the financial soundness of Islamic banks. Talking about loan to asset ratio it has positive relation with financial stability in case of Pakistan and UAE but negative in case of Bangladesh and Saudi Arabia. The difference can be attributed to the fact that Pakistan and UAE have good credit risk monitoring system in between bank and the borrowers, e.g. Small medium enterprises or companies as compared to that of Saudi Arabia and Bangladesh. Moreover, the results of cost to income ratio tell us that when Islamic Banks of Pakistan, UAE and Saudi Arabia raise their operating cost as a percentage of operating profits, it resultantly encourages financial stability. The same variable has negative relation with stability in Bangladesh, because their Islamic Banks cannot manage their operating costs effectively. In other words they have a high operational risk as compared to that of other countries in the sample. A direct relationship of growth in gross domestic product in UAE, Saudi Arabia and Pakistan suggests that GDP growth encourages financial stability of Islamic Banks in these three countries.

Taking ZScore as key indicator of financial stability as suggested by Husein (2014) we can see that Islamic banks in Bangladesh are less stable then the banks of Pakistan, as shown in Figure 1. On the other hand, if we take a look at the results of Islamic banks of Middle East, Banks in Saudi Arabia have high financial stability. To conclude we can say that Islamic banks of Middle East are more stable as compared to the Islamic banks of South Asia.

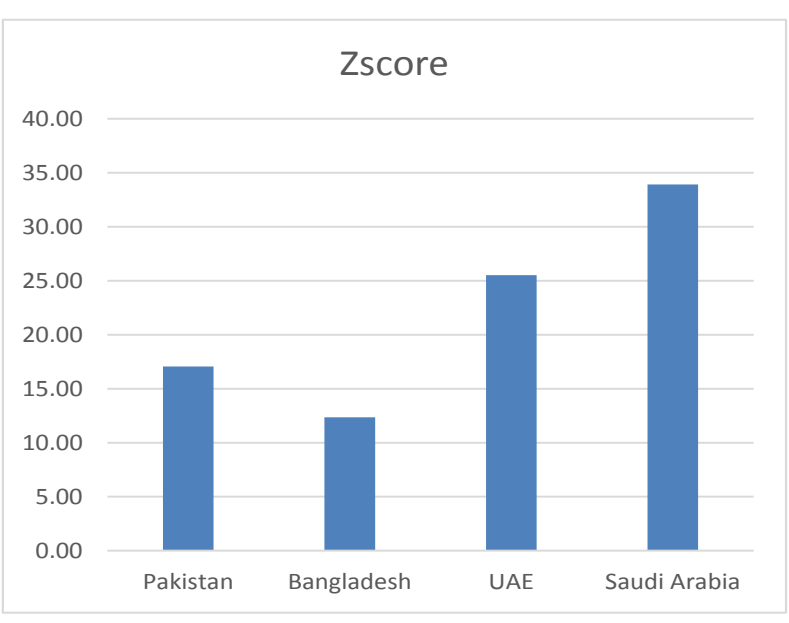

Figure 1: Z-score.

Following is the discussion of sample countries data on the basis of size. According to our designated criteria Pakistan has only one large bank that is Meezan Bank and rest of the banks in Pakistan are small banks. As per the comparison graph, it is shown that Small Islamic banks are more stable than large Islamic banks. On the other hand the Islamic banks of Saudi Arabia, UAE and Bangladesh are all large banks. So comparing 19 bank may not be an appropriate comparison, therefore, we just made comparison of small and large banks in Pakistan. On the basis of size Small Islamic banks are more stable than that of large Islamic Banks.

\subsection{Theoretical Contribution and Manage- rial Implication}

This study is pioneer in exploring the determinants of financial stability of Islamic Banks on Inter country level. It has contributed to the literature of Islamic finance and financial stability. This is first inter-country financial stability of Islamic banks study and thus is useful for internal as well as external users of financial information of shariah banks. Talking about internal users, inside policy makers of the Islamic banks can strive to diminish the elements that have negative relationship with financial stability; on the other hand, they can try to enhance the elements that have positive 
Table 4: Regression Results: Ordinary Least Squares (2008-2013)

\begin{tabular}{lcccccccc}
\hline Variable & Pakistan & Bangladesh & Saudi & United Arab & South Asian & Middle & All Banks \\
& & & & Arabia & Emirates & Banks & Eastern \\
& & & & & & \\
& & & & & \\
& & & & & \\
& & & & & \\
Constant & -11.44 & 18.144 & -25.634 & -29.705 & 18.344 & -12.429 & 18.144 \\
& $(0.000)^{* * *}$ & $(0.034)^{* *}$ & $(0.075)^{*}$ & $(0.000)^{* * *}$ & $(0.022)^{* *}$ & $(0.045)^{* *}$ & $(0.000)^{* * *}$ \\
Loan/Asset & -2.025 & 11.652 & -19.501 & 60.966 & 3.485 & -30.22 & 11.652 \\
& $(0.016)^{* *}$ & $(0.034)^{* *}$ & $(0.000)^{* * *}$ & $(0.000)^{* * *}$ & $(0.002)^{* * *}$ & $(0.005)^{* * *}$ & $(0.062)^{*}$ \\
Cost/Income & 1.613 & -9.924 & 59.539 & 7.436 & 1.442 & 11.186 & -9.924 \\
& $(0.000)^{* * *}$ & $(0.064)^{*}$ & $(0.000)^{* * *}$ & $(0.043)^{* *}$ & $(0.000)^{* * *}$ & $(0.028)^{* *}$ & $(0.054)^{* *}$ \\
GDP Growth & 1.587 & -2.85 & 4.402 & 2.561 & 1.144 & 2.182 & -2.85 \\
& $(0.000)^{* * *}$ & -0.104 & $(0.000)^{* * *}$ & $(0.000)^{* * *}$ & $(0.015)^{* *}$ & $(0.001)^{* * *}$ & $(0.001)^{* * *}$ \\
Inflation & 0.311 & 1.674 & & -0.501 & 0.905 & 1.716 & 1.674 \\
& $(0.000)^{* * *}$ & -0.223 & & $(0.000)^{* * *}$ & $(0.069)^{*}$ & $(0.000)^{* * *}$ & $(0.008)^{* * *}$ \\
R-Squared & 0.998 & 0.653 & 0.82 & 0.996 & 0.653 & 0.997 & 0.653 \\
\hline
\end{tabular}

p-values in parentheses

${ }^{*}$ significant at $10 \% ;{ }^{* *}$ significant at $5 \% ;{ }^{* *}$ significant at $1 \%$

relation with the financial stability of banks. Moreover, there are certain managerial implications of the study for external users as well. The study is useful for corporate customers, as well as other retail customers and depositors of the banks.

The study may also be useful for the governments and regulators of the respective countries.

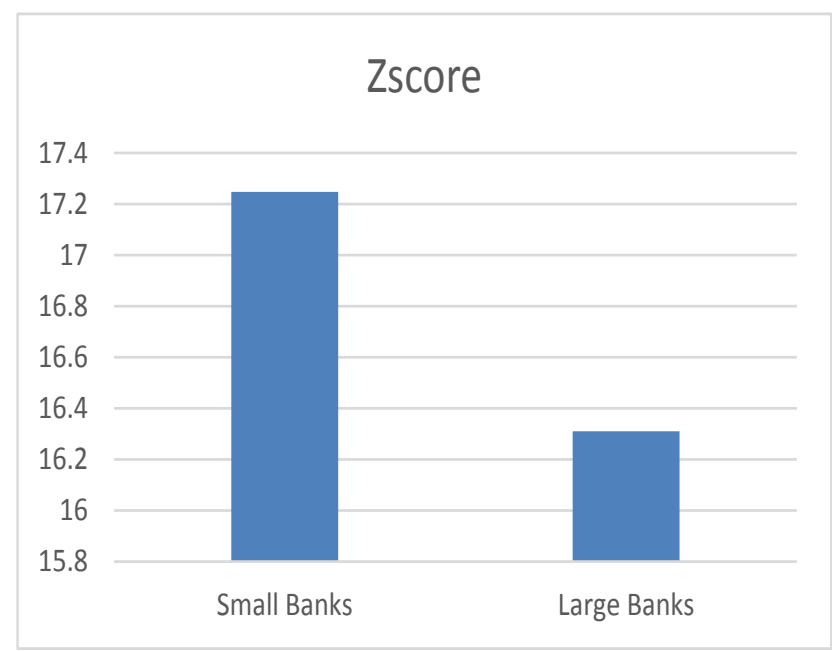

Figure 2: Z-score.

\section{Conclusion}

The present study has worked out first inter-country empirical analysis for exploring financial soundness of Islamic banks with Islamic banks. Z-scores have been used as a representative of stability. The findings suggests that (i) small Islamic banks are tend to be financially more sound and stable than larger Islamic banks; (ii) Islamic banks in UAE and Saudi Arabia (Middle East) are financially more stable and sound than the Islamic banks in Pakistan and Bangladesh (South Asia). The comparison between high financial stability in large Islamic banks and the comparatively low financial stability in small Islamic banks attracts the interest of researchers toward it. Results posit that, comparatively Islamic banks are more financially stable when conducting operations on a small scale, and are more likely to be financially stable when they are running their operations on a large scale. A reasonable interpretation for the results reported in the study propose that it is considerably more complicated for Islamic banks to adjust their credit risk checking system as soon as they grow larger in terms of total assets. Looking at their limitation in standardization of management of credit risk, and taking account of the numerous profit-lossinvestments become more complicated when the level of operations of the bank rises up. One more finding 
Table 5: Regression Results: Robust Estimation (2008-2013)

\begin{tabular}{|c|c|c|c|c|c|c|c|}
\hline Variable & Pakistan & Bangladesh & $\begin{array}{l}\text { Saudi } \\
\text { Arabia }\end{array}$ & $\begin{array}{c}\text { United Arab } \\
\text { Emirates }\end{array}$ & $\begin{array}{c}\text { South Asian } \\
\text { Banks }\end{array}$ & $\begin{array}{l}\text { Middle } \\
\text { Eastern } \\
\text { Banks }\end{array}$ & All Banks \\
\hline Constant & $\begin{array}{c}-11.325 \\
(0.000)^{* * *}\end{array}$ & $\begin{array}{c}17.104 \\
(0.035)^{* *}\end{array}$ & $\begin{array}{c}-12.106 \\
(0.000)^{* * *}\end{array}$ & $\begin{array}{c}-43.985 \\
(0.000)^{* * *}\end{array}$ & $\begin{array}{c}17.104 \\
(0.001)^{* *}\end{array}$ & $\begin{array}{c}-9.228 \\
(0.000)^{* * *}\end{array}$ & $\begin{array}{c}17.104 \\
(0.000)^{* * *}\end{array}$ \\
\hline Loan/Asset & $\begin{array}{c}-2.315 \\
(0.000)^{* * *}\end{array}$ & $\begin{array}{c}12.481 \\
(0.016)^{* *}\end{array}$ & $\begin{array}{c}-5.318 \\
(0.000)^{* * *}\end{array}$ & $\begin{array}{c}36.366 \\
(0.000)^{* * *}\end{array}$ & $\begin{array}{c}12.481 \\
(0.000)^{* * *}\end{array}$ & $\begin{array}{c}-7.816 \\
(0.000)^{* * *}\end{array}$ & $\begin{array}{c}12.481 \\
(0.000)^{* * *}\end{array}$ \\
\hline Cost/Income & $\begin{array}{c}1.615 \\
(0.000)^{* * *}\end{array}$ & $\begin{array}{c}-9.811 \\
(0.000)^{* * *}\end{array}$ & $\begin{array}{c}12.151 \\
(0.000)^{* * *}\end{array}$ & $\begin{array}{c}-10.537 \\
(0.000)^{* * *}\end{array}$ & $\begin{array}{c}-9.81 \\
(0.000)^{* * *}\end{array}$ & $\begin{array}{c}23.228 \\
(0.000)^{* * *}\end{array}$ & $\begin{array}{c}-9.814 \\
(0.000)^{* * *}\end{array}$ \\
\hline GDP Growth & $\begin{array}{c}1.588 \\
(0.000)^{* * *}\end{array}$ & $\begin{array}{c}-2.461 \\
0.148\end{array}$ & $\begin{array}{c}9.851 \\
(0.000)^{* * *}\end{array}$ & $\begin{array}{c}1.867 \\
(0.000)^{* * *}\end{array}$ & $\begin{array}{c}-2.461 \\
(0.031)^{* *}\end{array}$ & $\begin{array}{c}1.868 \\
(0.000)^{* * *}\end{array}$ & $\begin{array}{c}-2.461 \\
(0.001)^{* * *}\end{array}$ \\
\hline Inflation & $\begin{array}{c}0.312 \\
(0.000)^{* * *}\end{array}$ & $\begin{array}{c}1.415 \\
(0.293)\end{array}$ & & $\begin{array}{l}-0.462841 \\
(0.000)^{* * *}\end{array}$ & $\begin{array}{c}0.905 \\
(0.118)\end{array}$ & $\begin{array}{c}-30.221 \\
(0.000)^{* * *}\end{array}$ & $\begin{array}{c}1.415 \\
(0.023)^{* *}\end{array}$ \\
\hline R-Squared & 0.961 & 0.607 & 0.964 & 0.867 & 0.607 & 0.982 & 0.653 \\
\hline
\end{tabular}

which raises attention toward Islamic banks in Middle East is that they focus more on investments with low level of risk and fee income related to that investments and bank charges. On the other hand, Islamic banks in South Asia do more business in PLS Investments. The findings are in accordance with Cihák and Hesse (2008); Husein (2014); Shahid and Abbas (2012).

\subsection{Limitations}

One of the major limitations was no access to entire facts and figures of the used data, dependence on the unconsolidated financial statements data. Secondly, the current study has taken into account only those Islamic banks which are conducting all their operations according to the principles of Islamic finance and did not consider the banks which are conventional with Islamic "windows" or have only some Islamic branches being operated. Additionally, limitations of the data restricted from analyzing all the issues related to financial contracts of Islamic nature, such as, by differentiating between various investments and PLS arrangements. Moreover, it's not justifiable to generalize the results of this study on the basis of just four countries. Finally the data of initial years used in the study are possibly affected by and have the effects of global financial crises.

\subsection{Future Research Direction}

First of all the sample data selected for present study can be further prolonged to a larger number of countries and more number of banks, maybe by using data sources other than the sources that this study utilized. Also, the future researchers may effort to work on the financial stability effects of Islamic finance institutions of other types rather than the completely Islamic banks examined in present study, e.g. Islamic insurance companies and the commercial banks with Islamic windows.

\section{References}

Abedifar, P., Ebrahim, S. M., Molyneux, P., and Tarazi, A. (2015). Islamic banking and finance: Recent empirical literature and directions for future research. Journal of Economic Surveys, 29(4):637-670.

Ahmad, N. H. b., Noor, M. A. N. M., and Sufian, F. (2010). The efficiency of islamic banks: empirical evidence from the asian countries' islamic banking sectors. Journal for International Business and Entrepreneurship Development, 5(2):154166.

Ainley, M., Mashayekhi, A., Hicks, R., Rahman, A., and Ravalia, A. (2007). Islamic finance in the uk: Regula- 
tion and challenges. London: Financial Services Authority, page 13 .

Alanazi, E. S. M. and Lone, F. A. (2016). Social satisfaction towards islamic banking in saudi arabia: A survey. Asian Social Science, 12(1):182.

Barakat, H. J., Shatnawi, H. A., and Ismail, S. T. (2016). The role of marketing information systems in reducing the effects of the international financial crisis: A study applied on the banks working in the kingdom of saudi arabia from islamic perspective. International Journal of Marketing Studies, $8(1): 181$.

Bashir, A.-H. M. (2001). Assessing the performance of islamic banks: Some evidence from the middle east.

Boyd, J. H., Graham, S. L., and Hewitt, R. S. (1993). Bank holding company mergers with nonbank financial firms: Effects on the risk of failure. Journal of Banking $\mathcal{E}$ Finance, 17(1):43-63.

Boyd, J. H. and Runkle, D. E. (1993). Size and performance of banking firms: Testing the predictions of theory. Journal of monetary economics, 31(1):47-67.

Cihák, M. M. and Hesse, H. (2008). Islamic banks and financial stability: An empirical analysis. Number 8-16. International Monetary Fund.

De Nicolo, G. (2001). Size, charter value and risk in banking: An international perspective.

El Qorchi, M. (2005). Islamic finance gears up. Finance and Development, 42(4):46.

Hannan, T. H. and Hanweck, G. A. (1988). Bank insolvency risk and the market for large certificates of deposit. Journal of Money, Credit and Banking, 20(2):203-211.

Hassan, M. K. and Bashir, A.-H. M. (2003). Determinants of islamic banking profitability. In 10th ERF annual conference, Morocco, pages 16-18.

Hesse, H., Jobst, A. A., and Solé, J. (2008). Trends and challenges in islamic finance. World Economics, 9(2):175-193.

Husein, M. F. (2014). The stability of islamic banks in indonesia. In 2nd IBEA-International Conference on Business, Economics, and Accounting, pages 26-28.
Jobst, A. A. (2007). The economics of islamic finance and securitization. The Journal of Structured Finance, 13(1):6-27.

Kick, T. B. H. H. T. and von Westernhagen, N. (2009). Bank ownership and stability: evidence from germany. Issues.

Maji, S. G., Dey, S., and Jha, A. (2011). Insolvency risk of selected indian commercial banks: A comparative analysis. International Journal of Research in Commerce, Economics and Management, 1(5):120-124.

News, A. (2006). Saib launches islamic banking program. Annual Report (2011-2012).

Rana, F. (2006). Growing business prospect of islamic banking. The Daily Star, 28:5.

Samad, A. and Hassan, M. K. (1999). The performance of malaysian islamic bank during 1984-1997: An exploratory study. International Journal of Islamic Financial Services, 1(3):1-14.

SBP (2014). State bank of pakistan - islamic banking bulletin 2013-2014.

Shahid, M. A. and Abbas, Z. (2012). Financial stability of islamic banking in pakistan: An empirical study. African Journal of Business Management, 6(10):3706.

Shajari, P. and Mohebikhah, B. (2012). Financial stability in islamic banking system; the capacity to react to current world wide crisis. Money and Economy, 6(4).

Sole, J. A. (2007). Introducing islamic banks into coventional banking systems.

Sufian, F. (2007). The efficiency of islamic banking industry in malaysia: Foreign vs domestic banks. Humanomics, 23(3):174-192.

Sundararajan, V. and Errico, L. (2002). Islamic financial institutions and products in the global financial system: Key issues in risk management and challenges ahead, volume 2 . International Monetary Fund.

Uhde, A. and Heimeshoff, U. (2009). Consolidation in banking and financial stability in europe: Empirical evidence. Journal of Banking $\mathcal{E}$ Finance, 33(7):1299-1311.

Worrell, M. D., Maechler, A. M., and Mitra, M. S. (2007). Decomposing financial risks and vulnerabilities in Eastern Europe. Number 7-248. International Monetary Fund. 